\title{
Acute toxicity and anti-hyperglycemic activities of pomelo (Citrus grandis (L.) Osbeck) peel extracts in the Mekong Delta of Vietnam
}

\author{
Truc Thanh TRAN ${ }^{1,2 *}$, Nguyen Hong Khoi NGUYEN ${ }^{1,3}$, Mai Tuyet TRAN ${ }^{1}$, Tuan Trong NGUYEN ${ }^{4}$, \\ Truong Dang LE ${ }^{3,5 *}$ (D)
}

\begin{abstract}
The aim of this study was to investigate the total flavonoid content (TFC), vitamin C content, and the anti-hyperglycemic activities of pomelo peel extract (PPE) from the flavedo and albedo of two pomelo cultivars namely Long Co Co and Thanh Kieu in the Mekong Delta of Vietnam. Thanh Kieu PPE possessed the highest TFC of $11.18 \pm 0.14 \mathrm{mg} / 100 \mathrm{~g}$ from the albedo while the highest vitamin $C$ content was found in its flavedo $(47.74 \pm 0.34 \mathrm{mg} / 100 \mathrm{~g})$. PPE from the flavedo induced the mortality after 3-4 h of oral administration at a dosage of $5000 \mathrm{mg} / \mathrm{kg}$. In the contrast, PPE from the albedo was considered a non-toxic extract. Albedo PPE from two cultivars was observed to attenuate the blood glucose level of alloxan-hyperglycemia induced mice (from roughly $350 \mathrm{mg} / \mathrm{dL}$ to $150 \mathrm{mg} / \mathrm{dL}$ ) and there was no significant difference in the anti-hyperglycemic efficacy between albedo PPE and chemical drug (Glucophage). This finding showed potential in developing new functional food products or pharmaceutical alternatives from pomelo peels (an agro-waste) for anti-hyperglycemia.
\end{abstract}

Keywords: acute toxicity; anti-hyperglycemia; flavonoids; pomelo peel extract.

Practical Application: Anti-hyperglycemic effects of pomelo peel extracts.

\section{Introduction}

Pomelo fruits (Citrus grandis (L.) Osbeck), among citrus group, are the largest fruit with a round shape, greenish color, an average of $20 \mathrm{~cm}$ and $1-2 \mathrm{~kg}$ in diameter and weight (Chaiyana et al., 2014; Nur Salihah et al., 2015). In pomelo fruit, the endocarp (fresh flesh) is widely consumed due to its excellent performance in aroma and flavor, whereas the pomelo peel accounted for $20 \%$ of fruit weight is considered an agrowaste (Chaiyana et al., 2014; Tian et al., 2018). Along with primary metabolites in the pomelo peel including cellulose, hemicellulose, soluble sugars, lipid, polyphenols as secondary metabolites, mainly flavonoids are mostly found in the flavedo and albedo which possesses a diversity in health-promoting effects (Tocmo et al., 2020). However, the utilization of these pomelo peels has yet been economically feasible, leading to a large amount of pomelo peel disposal in the landfill and having a negative impact on the environmental issue (Zhu et al., 2017).

Phytochemical compounds from the pomelo peels has been currently gaining the interests in developing functionally health-beneficial products to reduce the overburden of landfills. He et al. (2012) attempted to extract flavonoids from the pomelo peel using supercritical carbon dioxide to employ beneficial aspects from the pomelo peel. The addition of pomelo peel into food was found to stimulate the growth of probiotics in the gastrointestinal tract, enhancing the gut health (Slavin, 2013).
Peroxide value was significantly reduced in fish treated with PPE, indicating the efficacy of PPE in the inhibition of lipid peroxidation (Zarina \& Tan, 2013). Type 2 diabetes mellitus is a major health problem which is usually characterized by the elevated glucose level in the bloodstream, insulin intolerance by insulin resistance or impaired insulin release rate (Jia et al., 2015; Kang et al., 2014). Flavonoids such as naringin, hesperidin, naringenin, quercetin, etc. have been reported to promote the anti-diabetic effects via the inhibition of carbohydrate digestive enzymes, alleviation of hyperglycemia, or improvement of utilization of glucose (Ahmed et al., 2017; Li et al., 2019; Proença et al., 2019; Shen et al., 2012; Şöhretoğlu \& Sari, 2020). Besides, using chemical drugs like Miglitol, Acarbose, or Voglibose was found to be associated with some adverse side effects for the diabetic patients such as diarrhea, abdominal distention, or flatulence (Proença et al., 2019; Şöhretoğlu \& Sari, 2020). Therefore, finding an effective means of natural drugs can be an ideal approach for antidiabetic treatment.

In the Mekong Delta of Vietnam, pomelo fruits contribute to a large segment of plant production. This means that tons of pomelo peels are discarded not perceiving the valuable sources of flavonoids from these peels. Two varieties of pomelo fruit including Thanh Kieu and Long Co Co in this region may play a certain role in promoting health-beneficial effects due to their

\footnotetext{
Received 20 Aug., 2021

Accepted 24 Sept., 2021

${ }^{1}$ College of Agriculture, Can Tho University, Can Tho City, Vietnam

${ }^{2}$ School of Graduate, Can Tho University, Can Tho City, Vietnam

${ }^{3}$ Faculty of Food and Environmental Engineering, Nguyen Tat Thanh University, Ho Chi Minh City, Vietnam

${ }^{4}$ College of Natural Sciences, Can Tho University, Can Tho City, Vietnam.

${ }^{5}$ Institute of Environmental Sciences, Nguyen Tat Thanh University, Ho Chi Minh City, Vietnam

*Corresponding author: tttruc@ctu.edu.vn; ldtruong@ntt.edu.vn
} 
flavonoids content in pomelo peels. Thus, this study aimed to evaluate the anti-hyperglycemic effect in vivo of extract from the flavedo and albedo of two cultivars. The revealed results can help facilitate to development of functional food products or pharmaceutical drugs from natural resources as well as easing the environmental problem.

\section{Materials and methods}

\subsection{Materials}

Pomelo fruits were harvested in the months from April to July. The Long Co Co pomelo and Thanh Kieu were yielded from Tien Giang province and Can Tho city of the Mekong Delta region. The peels were collected and washed to remove dirt. Pomelo peels from each cultivar were divided into two sections: flavedo (greenish peel) and albedo (white peel). They were then dried in the oven at $50{ }^{\circ} \mathrm{C}$ to reach the moisture content of $10 \%$. The dried peel was ground into the fine powder and prepared for ethanolic extraction (Zarina \& Tan, 2013).

Standard chemicals including 2,6-dichlorophenol-indophenol (DCPIP), ascorbic acid, quercetin, alloxan monohydrate, and Glucophage was purchased from Merck KGaA (Darmstadt, Germany). Other chemicals for experimental analysis were from the standard commercial supplies.

\subsection{Preparation of pomelo peel extract from the flavedo and albedo}

The ethanolic extraction method was applied to obtain the extract from pomelo peel as followed by the method of Abudayeh et al. (2019) with some adjustments. The as-prepared powder from the flavedo and albedo of each variety was mixed with ethanol solution at the ratio of $1: 2(\mathrm{w} / \mathrm{v})$ and $1: 4(\mathrm{w} / \mathrm{v})$, respectively. The mixture was continuously stirred for $2 \mathrm{~h}$ and subsequently filtrated using Whatman No 1 paper. This process was replicated five times. The volume of each filtrate was then concentrated using a rotary evaporator (IKA RV-3V, IKA ${ }^{\circ}$-Werke $\mathrm{GmbH} \& \mathrm{CO} . \mathrm{KG}$, Staufen, Germany) at $60^{\circ} \mathrm{C}$ until reaching the moisture content of the extract around $25 \%$. The pomelo peel extract (PPE) from the flavedo and albedo of each cultivar was stored and prepared for further analysis.

\subsection{Determination of total flavonoid content}

The total flavonoid content (TFC) was determined following the method of Mandal et al. (2013) with modifications. One mL of PPE was added to the mixture solution composed of $3 \mathrm{~mL}$ of methanol, $0.2 \mathrm{~mL}$ of $1 \mathrm{M} \mathrm{CH}_{3} \mathrm{COONa}, 0.2 \mathrm{~mL}$ of $\mathrm{AlCl}_{3}$, and $5.6 \mathrm{~mL}$ of distilled water. The mixture was allowed to stand for $30 \mathrm{~min}$ at room temperature and the absorbance was read at $415 \mathrm{~nm}$ using a 722-Visible spectrophotometer (China Yangzhou Wandong Medical Co., Ltd, China). The TFC was expressed as quercetin equivalent $(\mathrm{QE})$ using a quercetin standard curve (20-160 $\left.\mu \mathrm{g} / \mathrm{mL}, \mathrm{R}^{2}=0.9949\right)$. The unit was presented as $\mathrm{mg} \mathrm{QE} / \mathrm{g}$ dry matter (DM).

\subsection{Vitamin C determination}

The vitamin C content was evaluated according to AOAC 967.21 method with modifications (Association of Official Agricultural Chemists, 2006). Briefly, the mixture solution of $5 \mathrm{~mL}$ of PPE, $20 \mathrm{~mL}$ of $1 \% \mathrm{HCl}, 75 \mathrm{~mL}$ of $1 \%$ oxalic acid was allowed to react for $10 \mathrm{~min}$ and then filtrated using filter paper (Whatman No 1, UK). Subsequently, ten $\mathrm{mL}$ of the filtrate was titrated by using $0.001 \mathrm{~N}$ DCPIP solution until the presence of pale pink color persisted for 30 seconds. A blank sample was the mixture of $8 \mathrm{~mL}$ of $1 \%$ oxalic acid and $2 \mathrm{~mL}$ of $1 \% \mathrm{HCl}$. Ascorbic acid was used as a standard. The vitamin C content was expressed as $\mathrm{mg}$ per $100 \mathrm{~g}$ of dry matter.

\subsection{Acute toxicity study}

Male mice (Mus musculus var. albino) aged 8-10 weeks were purchased from the Pasteur Institute of Nha Trang, Vietnam. Mice were fed with commercial standard pellets $(2 \mathrm{~g})$ two times per day and housed in the animal cage, strictly adhering to the standard husbandry conditions with a $12 \mathrm{~h}$ light-dark cycle. For the acute toxicity study, mice were divided into 5 groups $(\mathrm{n}=5)$ and subjected to an oral gavage of $5000 \mathrm{mg} / \mathrm{kg}$ as a limit dose according to the OECD guidelines (Organization for Economic Cooperation and Development, 2008):

- Group 1: control mice without any treatment;

- Group 2: mice treated with PPE from the flavedo of Long Co Co variety at an oral dosage of $5000 \mathrm{mg} / \mathrm{kg}$;

- Group 3: mice treated with PPE from the albedo of Long Co Co variety at an oral dosage of $5000 \mathrm{mg} / \mathrm{kg}$;

- Group 4: mice treated with PPE from the flavedo of Thanh Kieu variety at an oral dosage of $5000 \mathrm{mg} / \mathrm{kg}$;

- Group 5: mice treated with PPE from the albedo of Thanh Kieu variety at an oral dosage of $5000 \mathrm{mg} / \mathrm{kg}$.

The post-dosing period of mice was evaluated in 14 days to observe body weight change, behavioral changes (salivation, diarrhea, lethargy, etc.), abnormal symptoms from the skin, fur, eyes, etc., or mortality as a result of toxicity signs (Ekanayake et al., 2019).

\subsection{Biochemical parameters and hematological analysis}

Mice after sacrifice, blood was taken from the inferior vena cava and divided into two groups in dry test tubes. Blood from the first group was allowed to coagulate at room temperature until complete clotting was observed. Serum was then centrifuged at $2000 \mathrm{rpm}$ for $10 \mathrm{~min}$ and separated to be prepared for biochemical parameters analysis. Alanine transaminase (ALT), aspartate transaminase (AST), creatinine, and urea values were measured by using an automated clinical chemistry analyzer (Siemens Healthineers AG, Erlangen, Germany) (Ali et al., 2019). The second group of blood samples was mixed with anticoagulant (EDTA) to evaluate hematological parameters: white blood cell (WBC), lymphocyte (LYMPH), mononucleosis (MONO), red blood cell (RBC), hemoglobin (HGB), hematocrit (HCT), mean corpuscular volume $(\mathrm{MCV})$, mean corpuscular hemoglobin $(\mathrm{MCH})$, mean 
corpuscular hemoglobin concentration (MCHC) and platelets (PLT) by using an auto hematology analyzer (BC-5390, Shenzhen Mindray Bio-Medical Electronics Co., Ltd., Shenzhen, China).

\subsection{Anti-hyperglycemic test}

To induce hyperglycemia, experimental mice were intraperitoneally injected with alloxan monohydrate $(135 \mathrm{mg} /$ $\mathrm{kg}$ body weight) each 1-day interval until reaching the blood glucose concentration of $200-300 \mathrm{mg} / \mathrm{dL}$. The mice were fasted for $18 \mathrm{~h}$ before taking the blood samples to evaluate the elevated glucose level (Saravanan \& Pari, 2005). For the anti-hyperglycemic therapy, model mice were divided into 5 groups:

- Group 1: control mice intraperitoneally injected with normal saline;

- Group 2: alloxan-hyperglycemia induced mice without treatment;

- Group 3: alloxan-hyperglycemia induced mice treated with Glucophage (two times per day) at an oral dosage of $108 \mathrm{mg} / \mathrm{kg}$;

- Group 4: alloxan-hyperglycemia induced mice treated with the Long Co Co albedo-PPE (two times per day) at an oral gavage of $400 \mathrm{mg} / \mathrm{kg}$;

- Group 5: alloxan-hyperglycemia induced mice treated with the Thanh Kieu albedo-PPE (two times per day) at an oral gavage of $400 \mathrm{mg} / \mathrm{kg}$;

Each 7-day interval, the body weight of model mice was recorded. After fasting for $18 \mathrm{~h}$, blood samples from the orbital veins were collected and centrifuged at $1500 \times \mathrm{g}$ for $20 \mathrm{~min}$ at $4^{\circ} \mathrm{C}$. The serum was stored at $-20^{\circ} \mathrm{C}$, and blood glucose levels were analyzed using a Glucose Assay Kit (Merck KGaA, Darmstadt, Germany) (Liu et al., 2021).

\subsection{Animal welfare}

The research was conducted upon the project B2020TCT-01, approved by the Director of the Department of Science, Technology and Environment, under the Minister of Education and Training of Vietnam on 9 January 2020. All experiments were carried out and strictly complied national guidelines on the protection of animals and experimental animal welfare in Vietnam following to Law on Animal Health, 2015, Vietnam National Assembly, No. 79/2015/QH13, approved 19 June 2015.

\subsection{Statistical analysis}

Each experimental data was analyzed using one-way analysis of variance (ANOVA) using SPSS software 20.0 (IBM Corp., Armonk, New York, USA). The group means were compared by using Duncan's multiple-range test and statistically significant difference was determined at the level of $5 \%(\mathrm{p}<0.05)$.

\section{Results and discussion}

\subsection{The total flavonoid content and vitamin $C$ content of PPE}

This study determined the TFC and vitamin C content of PPE from the flavedo and albedo of two cultivars: Long Co Co and Thanh Kieu and showed the statistically significant difference among analyzed groups, shown in Table 1. PPE from the albedo was considerably higher than the flavedo $(\mathrm{p}<0.05)$. The Thanh Kieu albedo PPE was found to contain the highest TFC, $11.18 \pm 0.14 \mathrm{mg}$ QE/g DM. The higher TFC in the albedo PPE in this study was in agreement with previous reports (Chang \& Azrina, 2017; Rahman et al., 2018). However, other studies showed that the flavedo possessed higher phenolic content than albedo (Tsai \& Wong, 2019; Xiao et al., 2021). This inconsistency was possibly derived from the discrepancy in pomelo varieties. Seven varieties of pomelo from Thailand was evaluated to compare their phenolic content, the result showed the fluctuation of phenolic content between the flavedo and albedo (Pichaiyongvongdee et al., 2014). These variations were ascribed to many possible variables including genetic factors, maturity stage, cultivation, harvest time, or post-harvesting conditions (Odriozola-Serrano et al., 2008; Shah et al., 2014; Toh et al., 2013). Shah et al. (2015) noted that some environmental factors such as temperature, light intensity, or processing treatment also partially influenced the phenolic content. Vitamin $\mathrm{C}$ is considered an essential phytochemical compound that is associated with some fundamental functions such as growth, maintenance of health, and metabolism (Gropper \& Smith, 2012). Vitamin C is also an antioxidant with the possibility of neutralizing the effects of free radicals and preventing some human diseases. In this study, the values of vitamin $\mathrm{C}$ content were ranged from 15.27 to $47.74 \mathrm{mg} / 100 \mathrm{~g}$ which were consistent with those of previous reports (Ani \& Abel, 2018; Toh et al., 2013). The highest content of vitamin $\mathrm{C}$ was found in the Thanh Kieu flavedo PPE with respect to $47.74 \pm 0.34 \mathrm{mg} / 100 \mathrm{~g}$. The PPE from the flavedo was observed with two-folds higher vitamin $\mathrm{C}$ content than the flavedo. The difference in the vitamin $\mathrm{C}$ content between varieties could possibly be attributed to climate conditions, cultural practices, maturity stages during harvesting or harvesting approach (Toh et al., 2013).

Table 1. Total flavonoid and vitamin C content of PPE.

\begin{tabular}{cccr}
\hline & Pomelo variety & $\begin{array}{c}\text { TFC } \\
(\mathrm{mg} \mathrm{QE} / \mathrm{g} \mathrm{DM})\end{array}$ & Vitamin C content (mg/100 g) \\
\hline Flavedo & Long Co Co & $10.10 \pm 0.09^{\mathrm{a}}$ & $41.42 \pm 0.41^{\mathrm{c}}$ \\
& Thanh Kieu & $10.61 \pm 0.17^{\mathrm{b}}$ & $47.74 \pm 0.34^{\mathrm{d}}$ \\
& Long Co Co & $9.98 \pm 0.11^{\mathrm{a}}$ & $23.54 \pm 0.36^{\mathrm{b}}$ \\
& Thanh Kieu & $11.18 \pm 0.14^{\mathrm{c}}$ & $15.27 \pm 0.44^{\mathrm{a}}$ \\
\hline
\end{tabular}

Data are expressed as mean \pm SD. Letters $(a, b, c, d)$ indicate statistically significant difference in mean values within the same column $(p<0.05)$. 


\subsection{Acute toxicity}

The administration of PPE from the flavedo and albedo of two cultivars: Long Co Co and Thanh Kieu at an oral gavage of $5000 \mathrm{mg} / \mathrm{kg}$ to evaluate the acute toxicity of PPE and was found to have a significant difference after 3-4 h of observation. $100 \%$ of death was observed in mice administered with flavedo PPE, whereas mice treated with albedo PPE did not appear any signs of toxicity at the end of the studied period (14 days). This indicated the non-toxicity of albedo PPE which was a safe extract for anti-hyperglycemia and the median lethal dose was expected to be higher than $5000 \mathrm{mg} / \mathrm{kg}$ (Iserhienrhien \& Okolie, 2020; Nguenang et al., 2020).

The change in body weight and hematological parameters of treated mice after the post-dosing period are listed in Table 2. The toxicity signs could probably be characterized by body weight loss of treated mice due to the induction of metabolism disorder after acute administration (Ali et al., 2019). The body weight of mice treated with albedo PPE from two varieties was found to be insignificant different $(p>0.05)$, indicating the normal state of health condition of albedo PPE treated mice. This trend was consistent with previous reports in the studies of acute toxicity (Ali et al., 2019; Ekanayake et al., 2019). The change in hematological parameters reflects the abnormalities in body metabolism or correlates to the body response to injures or lesions, deprivation, and stress (Dal Bosco et al., 2014). Results from the hematological analysis showed that WBC, LYMPH, MONO, MCV, MCH, and MCHC values of albedo PPE treated mice did not differ from those of the control group. The other hematological parameters such as RBC, HGB, HCT, and PLT showed a slight difference $(\mathrm{p}<0.05)$ compared to control mice. However, these variations were found to be within the acceptable range of healthy mice according to reported data of O’Connell et al. (2015).

The biochemical parameters of treated mice after the postdosing period are presented in Table 3 . Urea values of treated mice were similar to the control group, whereas albedo PPE treated mice showed a slight increment in creatinine values compared to the control mice. However, the increase of this value was still within the allowable limit of healthy mice (O'Connell et al., 2015). In terms of parameters indicating liver function, ALT and AST values showed a significant increase $(\mathrm{p}<0.05)$ as compared to the control group. Normally, the increase in these values is relatively associated with the damaged liver. Acute toxicity normally causes the elevation of the AST value which is higher than the ALT value and the ALT level should be 15-folds higher than the ALT level of the control group to inducing liver cell damage (Kim et al., 2008). In this study, AST values of treated mice were considerably less than the ALT values and the increment of ALT and AST values were found to be inadequate to induce the damage of the liver cells. In summary, results from hematological and serum biochemical parameters of treated mice demonstrated a normal state of health condition of studied mice. The same observed trend was found in the study of Ali et al. (2019).

\subsection{Anti-hyperglycemic effect of PPE in vivo}

The anti-hyperglycemic effects of PPE from the albedo of two varieties: Long Co Co and Thanh Kieu on the alloxanhyperglycemia induced mice were successfully evaluated via the observation of glucose levels in the bloodstream and body weight change of treated mice. Figure 1 shows the changes in

Table 2. Body weight gain and hematological parameters of treated mice after the post-dosing period.

\begin{tabular}{|c|c|c|c|}
\hline Parameters & Control mice & $\begin{array}{l}\text { Long Co Co albedo PPE-treated } \\
\text { mice }\end{array}$ & $\begin{array}{l}\text { Thanh Kieu albedo PPE-treated } \\
\text { mice }\end{array}$ \\
\hline $\mathrm{WBC}(\mathrm{K} / \mu \mathrm{L})$ & $4.58 \pm 0.65^{\mathrm{a}}$ & $3.38 \pm 1.64^{\mathrm{a}}$ & $4.10 \pm 1.05^{\mathrm{a}}$ \\
\hline MONO (\%) & $15.38 \pm 3.28^{\mathrm{a}}$ & $15.08 \pm 1.85^{\mathrm{a}}$ & $12.88 \pm 1.05^{\mathrm{a}}$ \\
\hline $\mathrm{RBC}(\mathrm{M} / \mu \mathrm{L})$ & $7.30 \pm 0.54^{\mathrm{a}}$ & $8.06 \pm 0.18^{\mathrm{b}}$ & $8.09 \pm 0.19^{\mathrm{b}}$ \\
\hline HGB (g/L) & $142 \pm 11.87^{\mathrm{a}}$ & $156.2 \pm 2.05^{\mathrm{b}}$ & $160.60 \pm 1.52^{b}$ \\
\hline MCV (fL) & $53.78 \pm 1.87^{\mathrm{a}}$ & $54.26 \pm 0.68^{\mathrm{a}}$ & $53.86 \pm 0.69^{\mathrm{a}}$ \\
\hline $\mathrm{MCH}(\mathrm{pg})$ & $19.38 \pm 0.44^{\mathrm{a}}$ & $19.18 \pm 0.23^{\mathrm{a}}$ & $19.18 \pm 0,08^{\mathrm{a}}$ \\
\hline $\mathrm{MCHC}(\mathrm{g} / \mathrm{L})$ & $361.60 \pm 15.85^{\mathrm{a}}$ & $348.80 \pm 6.46^{\mathrm{a}}$ & $354.20 \pm 7.56^{\mathrm{a}}$ \\
\hline $\operatorname{PLT}\left(10^{3} / \mu \mathrm{L}\right)$ & $413.80 \pm 25.84^{\mathrm{a}}$ & $744.00 \pm 159.64^{b}$ & $718.00 \pm 131.75^{b}$ \\
\hline
\end{tabular}

Each data is presented as mean \pm SD $(n=5)$. Superscripts $(a, b, c)$ show the statistically significant difference in mean values $(p<0.05)$ in the same row.

Table 3. Biochemical parameters of treated mice after the post-dosing period.

\begin{tabular}{crrr}
\hline Parameters & \multirow{2}{*}{ Control mice } & $\begin{array}{c}\text { Long Co Co albedo PPE-treated } \\
\text { mice }\end{array}$ & $\begin{array}{c}\text { Thanh Kieu albedo PPE-treated } \\
\text { mice }\end{array}$ \\
\hline Urea $(\mathrm{mmol} / \mathrm{L})$ & $6.00 \pm 0.58^{\mathrm{a}}$ & $7.29 \pm 1.36^{\mathrm{a}}$ & $7.19 \pm 1.76^{\mathrm{a}}$ \\
Creatinine $(\mu \mathrm{mol} / \mathrm{L})$ & $79.20 \pm 1.30^{\mathrm{a}}$ & $98.60 \pm 16.35^{\mathrm{b}}$ & $123.60 \pm 7.16^{\mathrm{c}}$ \\
ALT (U/L) & $75.60 \pm 9.94^{\mathrm{a}}$ & $198.00 \pm 47.12^{\mathrm{b}}$ & $144.00 \pm 24.08^{\mathrm{b}}$ \\
AST (U/L) & $40.60 \pm 2.51^{\mathrm{a}}$ & $112.00 \pm 19.24^{\mathrm{b}}$ & $122.00 \pm 13.04^{\mathrm{b}}$ \\
\hline
\end{tabular}

Data are expressed as mean \pm SD $(n=5)$. Letters $(a, b, c)$ in the same row indicate the significant difference in mean values at the level of $5 \%(p<0.05)$. 


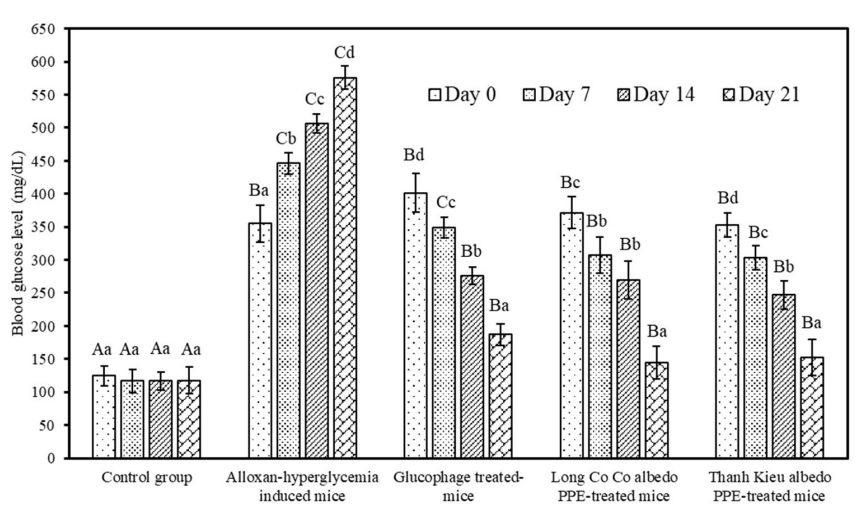

Figure 1. Blood glucose levels of alloxan-hyperglycemia induced mice at different treatment conditions. Superscripts (a, b, c, d) show the significant difference in blood glucose levels at the same treatment group during different studied periods. Capital letters (A, B, C) present the significant difference in blood glucose levels of treatment groups at the same studied period.

blood glucose levels of hyperglycemic mice at different treatment conditions. Control mice appeared to have stabilized levels of glucose in the bloodstream, approximately $125 \mathrm{mg} / \mathrm{dL}$. The blood glucose levels of alloxan-hyperglycemic mice were in the range of 350-400 mg/dL (> $200 \mathrm{mg} / \mathrm{dL}$ ), indicating the excess glucose level in mice (Liauw et al., 2008). The elevation of glucose level was ascribed to the insufficient insulin secretion, insensitivity of insulin, preventing the diffusion of glucose to muscle cells, leading to the decrement in glucose utilization (Chandalia et al., 2000). Blood glucose level of non-treated mice was found to gradually increase during the observed period, which was in agreement with previous study (Ahmad et al., 2018). Glucophage drug returned hyperglycemic mice to normal glucose level at $187.2 \pm$ $16.47 \mathrm{mg} / \mathrm{dL}$. Mice treated with albedo PPE from Long Co Co and Thanh Kieu variety were found to have the alleviated glucose level on day 21. The glucose levels in mice treated with Long Co Co and Thanh Kieu albedo PPE were reduced to $144.36 \pm$ $24.87 \mathrm{mg} / \mathrm{dL}$ and $152.64 \pm 27.32 \mathrm{mg} / \mathrm{dL}$, respectively. There was an insignificant difference in reducing glucose level of mice treated with Glucophage, Long Co Co albedo PPE, and Thanh Kieu albedo PPE ( $>0.05)$ on day 21 , indicating the effective therapy from the albedo PPE as compared to the commercial drug (Glucophage). Ahmad et al. (2018) revealed the similar finding in PPE to reduce elevated blood glucose levels. This anti-hyperglycemic effect was also found in other citrus peel extracts (Ahmed et al., 2017; Ali et al., 2020; Fayek et al., 2017).

The anti-hyperglycemic effect of albedo PPE could possibly be ascribed to the presence of flavonoid compounds. Primary flavonoids in pomelo peel such as naringenin and hesperidin were found to be responsible for the anti-hyperglycemic effect via the inhibition of carbohydrate digestive enzymes, resulting in a delay in the absorption of carbohydrates in hyperglycemic mice (Jung et al., 2004). KunduSen et al. (2011) noted that hesperidin could possibly possess the ability to protect pancreatic Beta-cell from STZ actions and restore their ability to secrete insulin. Naringin and neohesperidin in the citrus peel extract were found to modulate hepatic glucokinase activity while

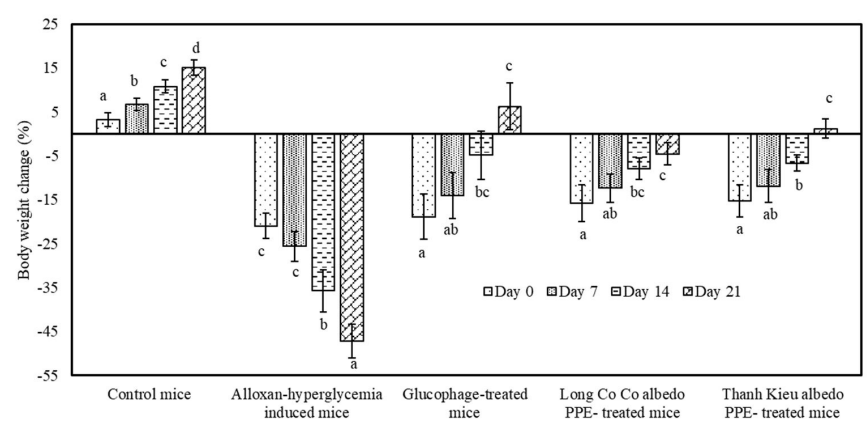

Figure 2. Body weight changes of alloxan-hyperglycemia induced mice at different oral treatments during 21 days-period. Superscripts ( $a, b$, c) indicate the significant difference in mean values within the same treatment group. Negative values indicate body weight loss and positive values show the body weight gain of treated mice.

inactivating phosphoenolpyruvate carboxykinase and hepatic glucose-6-phosphatase, resulting in the attenuation of glucose level (Jung et al., 2004; Zhang et al., 2012).

Figure 2 presents the body weight changes of hyperglycemic mice during 21 days of the therapy using albedo PPE at a daily oral dosage of $400 \mathrm{mg} / \mathrm{kg}$. Control mice showed continuous body weight gain during the observed period, indicating the normal state of health condition. During the period of inducing hyperglycemia on tested mice, the body weight of mice was found to decrease to $20.94 \pm 2.92 \%$ and started continuously dropping to $47.23 \pm 3.81 \%$ on day 21 . A similar trend was observed in the study of Liu et al. (2021). Glucophage-treated mice was found to have the return in the body weight after 21 days, from $-18.85 \pm 5.08 \%$ to $6.21 \pm 5.33 \%(\mathrm{p}<0.05)$. The weight loss of hyperglycemic mice treated with albedo PPE was found to be significantly alleviated ( $\mathrm{p}<0.05)$. The body weight loss of Long Co Co albedo PPE-treated mice was attenuated to $4.56 \pm 2.54 \%$, whereas the Thanh Kieu albedo PPE-treated mice were found to have a weight gain of $1.21 \%$ on day 21 . The increment of body weight of treated mice was observed after the therapy as the severity of hyperglycemia was attenuated (Liu et al., 2021).

\section{Conclusion}

In this study, PPE from the flavedo and albedo of two pomelo varieties: Long Co Co and Thanh Kieu were successfully evaluated. The total flavonoid content was relatively insignificant in the flavedo and albedo PPE of the two cultivars, whereas vitamin $\mathrm{C}$ was significantly predominant in the flavedo PPE. The flavedo PPE induced $100 \%$ mortality of treated mice, whereas the albedo PPE was observed to be a non-toxic extract with a median lethal dose of greater than $5000 \mathrm{mg} / \mathrm{kg}$. The Long Co Co, Thanh Kieu albedo PPE, and Glucophage were found to have the same efficacy in attenuating the elevated glucose levels in alloxan-hyperglycemic mice. The use of Long Co Co and Thanh Kieu albedo PPE could be a potent approach for anti-hyperglycemia therapy.

\section{Conflict of interest}

The authors declare no conflict of interest. 


\section{Acknowledgements}

This research was funded by the B2020-TCT-01 project from the Ministry of Education and Training, Vietnam.

\section{References}

Abudayeh, Z. H., Al Khalifa, I. I., Mohammed, S. M., \& Ahmad, A. A. (2019). Phytochemical content and antioxidant activities of pomelo peel extract. Pharmacognosy Research, 11(3), 244-247. http://dx.doi. org/10.4103/pr.pr_180_18.

Ahmad, A. A., Al Khalifa, I. I., \& Abudayeh, Z. H. (2018). The role of pomelo peel extract for experimentally induced wound in diabetic rats. Pharmacognosy Journal, 10(5), 885-891. http://dx.doi. org/10.5530/pj.2018.5.149.

Ahmed, O. M., Hassan, M. A., Abdel-Twab, S. M., \& Abdel Azeem, M. N. (2017). Navel orange peel hydroethanolic extract, naringin and naringenin have anti-diabetic potentials in type 2 diabetic rats. Biomedicine and Pharmacotherapy, 94, 197-205. http://dx.doi. org/10.1016/j.biopha.2017.07.094. PMid:28759757.

Ali, A. M., Gabbar, M. A., Abdel-twab, S. M., Fahmy, E. M., Ebaid, H., Alhazza, I. M., \& Ahmed, O. M. (2020). Antidiabetic potency, antioxidant effects, and mode of actions of Citrus reticulata fruit peel hydroethanolic extract, hesperidin, and quercetin in nicotinamide/streptozotocin-induced wistar diabetic rats. Oxidative Medicine and Cellular Longevity, 2020, 1730492. http://dx.doi. org/10.1155/2020/1730492. PMid:32655759.

Ali, M. Y., Rumpa, N. E. N., Paul, S., Hossen, M. S., Tanvir, E. M., Hossan, T., Saha, M., Alam, N., Karim, N., Khalil, M. I., \& Gan, S. H. (2019). Antioxidant potential, subacute toxicity, and beneficiary effects of methanolic extract of pomelo (Citrus grandis L. Osbeck) in long evan rats. Journal of Toxicology, 2019, 2529569. http://dx.doi. org/10.1155/2019/2529569. PMid:31281355.

Ani, P. N., \& Abel, H. C. (2018). Nutrient, phytochemical, and antinutrient composition of Citrus maxima fruit juice and peel extract. Food Science \& Nutrition, 6(3), 653-658. http://dx.doi.org/10.1002/ fsn3.604. PMid:29876116.

Association of Official Agricultural Chemists - AOAC. (2006). AOAC official method 45.1.14: ascorbic acid in vitamin preparations and juices, 2,6 dichloroindophenol titrimetric method (pp. 1-2). Arlington: AOAC.

Chaiyana, W., Phongpradist, R., \& Leelapornpisid, P. (2014). Characterization of hydrodistillated pomelo peel oil and the enhancement of biological activities using microemulsion formulations. International Journal of Pharmacy and Pharmaceutical Sciences, 6(9), 596-602.

Chandalia, M., Garg, A., Lutjohann, D., Von Bergmann, K., Grundy, S. M., \& Brinkley, L. J. (2000). Beneficial effects of high dietary fiber intake in patients with type 2 diabetes mellitus. The New England Journal of Medicine, 342(19), 1392-1398. http://dx.doi.org/10.1056/ NEJM200005113421903. PMid:10805824.

Chang, S. Q., \& Azrina, A. (2017). Antioxidant content and activity in different parts of pomelo [Citrus grandis (L.) Osbeck] by-products. Acta Horticulturae, (1152), 27-34. http://dx.doi.org/10.17660/ ActaHortic.2017.1152.4.

O’Connell, K. E., Mikkola, A. M., Stepanek, A. M., Vernet, A., Hall, C. D., Sun, C. C., Yildirim, E., Staropoli, J. F., Lee, J. T., \& Brown, D. E. (2015). Practical murine hematopathology: a comparative review and implications for research. Comparative Medicine, 65(2), 96-113. PMid:25926395.

Dal Bosco, A., Gerencsér, Z., Szendrő, Z., Mugnai, C., Cullere, M., Kovàcs, M., Ruggeri, S., Mattioli, S., Castellini, C., \& Dalle Zotte, A. (2014). Effect of dietary supplementation of Spirulina (Arthrospira platensis) and Thyme (Thymus vulgaris) on rabbit meat appearance, oxidative stability and fatty acid profile during retail display. Meat Science, 96(1), 114-119. http://dx.doi.org/10.1016/j.meatsci.2013.06.021. PMid:23896145.

Ekanayake, C. P., Thammitiyagodage, M. G., Padumadasa, S., Seneviratne, B., Padumadasa, C., \& Abeysekera, A. M. (2019). Acute and subacute toxicity studies of the ethyl acetate soluble proanthocyanidins of the immature inflorescence of Cocos nucifera L. in female Wistar rats. BioMed Research International, 2019, 8428304. http://dx.doi. org/10.1155/2019/8428304. PMid:31886260.

Fayek, N. M., El-shazly, A. H., Abdel-monem, A. R., Moussa, M. Y., Abd-elwahab, S. M., \& El-tanbouly, N. D. (2017). Comparative study of the hypocholesterolemic, antidiabetic effects of four agro-waste Citrus peels cultivars and their HPLC standardization. Revista Brasileira de Farmacognosia, 27(4), 488-494. http://dx.doi. org/10.1016/j.bjp.2017.01.010.

Gropper, S. S., \& Smith, J. L. (2012). Advanced nutrition and human metabolism. Belmont: Cengage Learning.

He, J. Z., Shao, P., Liu, J. H., \& Ru, Q. M. (2012). Supercritical carbon dioxide extraction of flavonoids from pomelo (citrus grandis (L.) osbeck) peel and their antioxidant activity. International Journal of Molecular Sciences, 13(10), 13065-13078. http://dx.doi.org/10.3390/ ijms131013065. PMid:23202938.

Iserhienrhien, O. L., \& Okolie, P. N. (2020). Acute and sub-acute toxicity profile of methanol leaf extract of Geophila obvallata on renal and hepatic indices in Wistar rats. Cogent Food \& Agriculture, 6(1), 1794240. http://dx.doi.org/10.1080/23311932.2020.1794240.

Jia, S., Hu, Y., Zhang, W., Zhao, X., Chen, Y., Sun, C., Li, X., \& Chen, K. (2015). Hypoglycemic and hypolipidemic effects of neohesperidin derived from Citrus aurantium L. in diabetic KK-Ay mice. Food \& Function, 6(3), 878-886. http://dx.doi.org/10.1039/C4FO00993B. PMid:25620042.

Jung, U. J., Lee, M.-K., Jeong, K.-S., \& Choi, M.-S. (2004). The hypoglycemic effects of hesperidin and naringin are partly mediated by hepatic glucose-regulating enzymes in C57BL/KsJ-db/db mice. The Journal of Nutrition, 134(10), 2499-2503. http://dx.doi.org/10.1093/ jn/134.10.2499. PMid:15465737.

Kang, B. H., Racicot, K., Pilkenton, S. J., \& Apostolidis, E. (2014). Evaluation of the in vitro anti-hyperglycemic effect of cinnamomum cassia derived phenolic phytochemicals, via carbohydrate hydrolyzing enzyme inhibition. Plant Foods for Human Nutrition, 69(2), 155160. http://dx.doi.org/10.1007/s11130-014-0415-z. PMid:24706251.

Kim, W. R., Flamm, S. L., Di Bisceglie, A. M., \& Bodenheimer, H. C. (2008). Serum activity of alanine aminotransferase (ALT) as an indicator of health and disease. Hepatology, 47(4), 1363-1370. http:// dx.doi.org/10.1002/hep.22109. PMid:18366115.

KunduSen, S., Gupta, M., Mazumder, U. K., Haldar, P. K., Saha, P., Bhattacharya, S., Kar, B., \& Bala, A. (2011). Antihyperglycemic effect and antioxidant property of Citrus maxima leaf in streptozotocininduced diabetic rats. Diabetologia Croatica, 40(4).

Li, Y., Kandhare, A. D., Mukherjee, A. A., \& Bodhankar, S. L. (2019). Acute and sub-chronic oral toxicity studies of hesperidin isolated from orange peel extract in Sprague Dawley rats. Regulatory Toxicology and Pharmacology, 105, 77-85. http://dx.doi.org/10.1016/j. yrtph.2019.04.001. PMid:30991075.

Liauw, M. Y., Natan, F. A., Widiyanti, P., Ikasari, D., Indraswati, N., \& Soetaredjo, F. E. (2008). Extraction of neem oil (Azadirachta indica A. Juss) using n-hexane and ethanol: studies of oil quality, kinetic and thermodynamic. Journal of Engineering and Applied Sciences, 3(3), 49-54. 
Liu, H., Zeng, X., Huang, J., Yuan, X., Wang, Q., \& Ma, L. (2021). Dietary fiber extracted from pomelo fruitlets promotes intestinal functions, both in vitro and in vivo. Carbohydrate Polymers, 252, 117186. http://dx.doi.org/10.1016/j.carbpol.2020.117186. PMid:33183633.

Mandal, S., Patra, A., Samanta, A., Roy, S., Mandal, A., Mahapatra, T. D., Pradhan, S., Das, K., \& Nandi, D. K. (2013). Analysis of phytochemical profile of Terminalia arjuna bark extract with antioxidative and antimicrobial properties. Asian Pacific Journal of Tropical Biomedicine, 3(12), 960-966. http://dx.doi.org/10.1016/ S2221-1691(13)60186-0. PMid:24093787.

Nguenang, G. S., Ntyam, A. S. M., \& Kuete, V. (2020). Acute and subacute toxicity profiles of the methanol extract of Lycopersicon esculentum L. leaves (tomato), a botanical with promising in vitro anticancer potential. Evidence-Based Complementary and Alternative Medicine, 2020, 8935897. http://dx.doi.org/10.1155/2020/8935897. PMid:32215048.

Nur Salihah, B., Rosnah, S., \& Norashikin, A. A. (2015). Mass modeling of Malaysian varieties pomelo fruit (Citrus grandis L. Osbeck) with some physical characteristics. International Food Research Journal, 22(2), 488-493.

Odriozola-Serrano, I., Soliva-Fortuny, R., \& Martín-Belloso, O. (2008). Changes of health-related compounds throughout cold storage of tomato juice stabilized by thermal or high intensity pulsed electric field treatments. Innovative Food Science \& Emerging Technologies, 9(3), 272-279. http://dx.doi.org/10.1016/j.ifset.2007.07.009.

Organization for Economic Cooperation and Development - OECD. (2008). Test $n^{\circ}$. 425: acute oral toxicity: up-and-down procedure (pp. 1-21). Paris: OECD.

Pichaiyongvongdee, S., Rattanapun, B., \& Haruenkit, R. (2014). Total polyphenol content and antioxidant properties in different tissues of seven pomelo (Citrus grandis (L.) osbeck) cultivars. Witthayasan Kasetsat Witthayasat, 48(6), 989-996.

Proença, C., Freitas, M., Ribeiro, D., Tomé, S. M., Oliveira, E. F. T., Viegas, M. F., Araújo, A. N., Ramos, M. J., Silva, A. M. S., Fernandes, P. A., \& Fernandes, E. (2019). Evaluation of a flavonoids library for inhibition of pancreatic $\alpha$-amylase towards a structure-activity relationship. Journal of Enzyme Inhibition and Medicinal Chemistry, 34(1), 577-588. http://dx.doi.org/10.1080/14756366.2018.1558221 . PMid:30724629.

Rahman, N. F. A., Shamsudin, R., Ismail, A., Shah, N. N. A. K., \& Varith, J. (2018). Effects of drying methods on total phenolic contents and antioxidant capacity of the pomelo (Citrus grandis (L.) Osbeck) peels. Innovative Food Science \& Emerging Technologies, 50, 217-225. http://dx.doi.org/10.1016/j.ifset.2018.01.009.

Saravanan, R., \& Pari, L. (2005). Antihyperlipidemic and antiperoxidative effect of Diasulin, a polyherbal formulation in alloxan induced hyperglycemic rats. BMC Complementary and Alternative Medicine, 5(1), 14. http://dx.doi.org/10.1186/1472-6882-5-14. PMid:15969768.

Shah, N. N. A. K., Rahman, R. A., Shamsuddin, R., \& Adzahan, N. M. (2015). Effects of pectinase clarification treatment on phenolic compounds of pummelo (Citrus grandis L. Osbeck) fruit juice. Journal of Food Science and Technology, 52(8), 5057-5065. http:// dx.doi.org/10.1007/s13197-014-1554-9. PMid:26243926.
Shah, N. N. A. K., Shamsuddin, R., Rahman, R. A., \& Adzahan, N. M. (2014). Effects of physicochemical characteristics of pummelo fruit juice towards UV inactivation of Salmonella typhimurium. Agriculture and Agricultural Science Procedia, 2, 43-52. http://dx.doi. org/10.1016/j.aaspro.2014.11.007.

Shen, W., Xu, Y., \& Lu, Y. H. (2012). Inhibitory effects of Citrus flavonoids on starch digestion and antihyperglycemic effects in HepG2 cells. Journal of Agricultural and Food Chemistry, 60(38), 9609-9619. http://dx.doi.org/10.1021/jf3032556. PMid:22958058.

Slavin, J. (2013). Fiber and prebiotics: mechanisms and health benefits. Nutrients, 5(4), 1417-1435. http://dx.doi.org/10.3390/nu5041417. PMid:23609775.

Şöhretoğlu, D., \& Sari, S. (2020). Flavonoids as alpha-glucosidase inhibitors: mechanistic approaches merged with enzyme kinetics and molecular modelling. Phytochemistry Reviews, 19(5), 1081-1092. http://dx.doi.org/10.1007/s11101-019-09610-6.

Tian, X., Liu, Y., Feng, X., Khaskheli, A. A., Xiang, Y., \& Huang, W. (2018). The effects of alcohol fermentation on the extraction of antioxidant compounds and flavonoids of pomelo peel. LebensmittelWissenschaft + Technologie, 89, 763-769. http://dx.doi.org/10.1016/j. lwt.2017.11.049.

Tocmo, R., Pena-Fronteras, J., Calumba, K. F., Mendoza, M., \& Johnson, J. J. (2020). Valorization of pomelo (Citrus grandis Osbeck) peel: a review of current utilization, phytochemistry, bioactivities, and mechanisms of action. Comprehensive Reviews in Food Science and Food Safety, 19(4), 1969-2012. http://dx.doi.org/10.1111/15414337.12561. PMid:33337092.

Toh, J. J., Khoo, H. E., \& Azrina, A. (2013). Comparison of antioxidant properties of pomelo [Citrus grandis (L) Osbeck] varieties. International Food Research Journal, 20(4), 1661-1668.

Tsai, W. C., \& Wong, Y. H. (2019). a-glucosidase inhibitory activity and antioxidant activity of pomelo (Citrus grandis) peel, albedo, and flavedo extracts. Taiwanese Journal of Agricultural Chemistry and Food Science, 57(4), 173-180. http://dx.doi.org/10.6578/ TJACFS.201908_57(4).0002.

Xiao, L., Ye, F., Zhou, Y., \& Zhao, G. (2021). Utilization of pomelo peels to manufacture value-added products: a review. Food Chemistry, 351, 129247. http://dx.doi.org/10.1016/j.foodchem.2021.129247. PMid:33640768.

Zarina, Z., \& Tan, S. Y. (2013). Determination of flavonoids in Citrus grandis (Pomelo) peels and their inhibition activity on lipid peroxidation in fish tissue. International Food Research Journal, 20(1), 313-317.

Zhang, J., Sun, C., Yan, Y., Chen, Q., Luo, F., Zhu, X., Li, X., \& Chen, K. (2012). Purification of naringin and neohesperidin from Huyou (Citrus changshanensis) fruit and their effects on glucose consumption in human HepG2 cells. Food Chemistry, 135(3), 1471-1478. http:// dx.doi.org/10.1016/j.foodchem.2012.06.004. PMid:22953882.

Zhu, J., Liu, Q., Li, Z., Liu, J., Zhang, H., Li, R., Wang, J., \& Emelchenko, G. A. (2017). Recovery of uranium (VI) from aqueous solutions using a modified honeycomb-like porous carbon material. Dalton Transactions, 46(2), 420-429. http://dx.doi.org/10.1039/C6DT03227C. PMid:27929585. 